\title{
The Benefits of Management and Organisation: A Case Study in Young Language Learners' Classrooms
}

Christina Nicole Giannikas ${ }^{1}$

$\approx$ This study focuses on primary language education within a Greek region: specifically, on the positive effects of classroom management and organisation on a student-centred approach of teaching. In the case of the Greek education system, language teachers are encouraged to adopt student-centred approaches in their classroom but have not received any guidance on how to do so. Language educators are reluctant to abandon their teacher-centred ways, because they have not been trained to apply classroom management and organisation techniques that could support a student-centred environment.

Keywords: Classroom management and organisation; Young learners; Student-centred approaches; Classroom environment; Classroom layouts; Action research; Qualitative research 


\section{Prednosti vodenja in organizacije razreda: študija primera poučevanja jezika mlajših učencev}

\section{Christina Nicole Giannikas}

$\approx$ Prispevek se osredinja na poučevanje tujega jezika v Grčiji na razredni stopnji, še posebej na pozitivne učinke vodenja razreda in organizacije pri poučevanju, kjer je v središču učenec. V grškem izobraževalnem sistemu se prav učitelje jezikov spodbuja, da za poučevanje izbirajo pristope, pri katerih so v središču učenci, vendar pa za tak način dela niso dobili nikakršnih smernic. Prav zato, ker učitelji jezikov niso usposobljeni za vodenje razreda in organizacijo, ki bi pripomogla k vzpostaviti učnega okolja, v katerem je v središču učenec, so nenaklonjeni opustitvi pristopov, pri katerih je v ospredju učitelj.

Ključne besede: vodenje razreda in organizacija v razredu, mlajši učenci, pristopi, pri katerih je v središču učenec, razredno okolje, ureditev razreda, akcijsko raziskovanje, kvalitativna raziskava 


\section{Introduction}

Although there has been significant research in the field of young learners of English, there has been little focus on classroom management, organisation and learner-centred classrooms within a Greek context. While the nature of classroom management and interaction has been a topic of extensive research in language learning and education in general, language lessons continue to be carried out in a rather traditional manner in Greek primary schools. A teacher-centred strategy prevails in most classrooms, based on the general beliefs and values of Greek language teachers, as it is considered to be conducive to student learning (Rixon, 1999).

A feeling of community can be argued to be imperative to successful language learning and learning in general. Educators are expected to create an environment advantageous to student learning where young language learners (YLLs) can feel sufficiently inspired to achieve their goals and leave the classroom feeling confident about themselves. In order for this to be accomplished, a certain procedure must be established. According to Paulsel (2004), teachers learn to establish routines, develop classroom rules to maintain order, and arrange the classroom in such a way as to facilitate the learning process. The teaching environment could be seen as comprising three components: social, physical and educational. Teaching intentions can be communicated to language learners by the way the environment is organised: it can reveal what it is they can anticipate from this experience.

With the intention of accomplishing successful interaction and group activities, a teacher must be aware of the importance of appropriate management in the classroom. Providing a suitable atmosphere during the lesson is essential, so that students can feel secure and confident. Kaulfer (2006) believes in the significance of organised classroom management can be effective in all teaching situations, by supporting the notion that the principles of classroom management, efficient ordering of the language-learning environment and the effective control of discipline. The foreign language class, with the nature of its subject matter taken into account, can provide many opportunities for unique and creative types of control, a luxury other curriculum areas do not have.

In this paper, I will present the significance of classroom management and organisation through a case study conducted within a region in south-western Greece. The main focus of the research is to what extent state schools and private language schools in Greece provide language-learning opportunities within an age-appropriate environment and how the management techniques used affect and benefit YLLs. 


\section{Research Methods}

This study was separated in two parts; the first focused on language teaching in seven state schools and seven private language schools (frodistiria: the Greek term that will be used throughout) across the region. The schools were selected so that all societal backgrounds of language learners are covered. This section will present the research design and methodological approach employed to investigate early language teaching within a Greek regional context. Due to the complexity of English language education in the region where the case study took place, a multi-method research approach was designed to carry out the study and present valuable data that will contribute to the field of early language learning. In this case, there has been an integration of qualitative and action research, which draws on qualitative methods, supported by elements of quantitative evidence. This combination allows the researcher to not only describe events but explore how the phenomena occur and provide a valid contribution and evaluation. In the case of the current study, qualitative research (including both classroom study and action research) gave the researcher the opportunity to observe the given situation, to interact with the participants, and to gain insights and information from the participants' point of view and experience.

The following visual representation is used to clearly show the different phases of the research, the various types of data collecting tools in each phase, the number of participants and the time period spent.

Table 1. Different Phases of the Research.

\begin{tabular}{|c|c|c|c|c|}
\hline Phases & Time Period & Institution & Participants & Data Collection tools \\
\hline \multirow[t]{2}{*}{ Phase 1} & $2007-2008$ & 7 State Schools & 151Ss-7Ts & Class Observations-Teacher \\
\hline & & & & Interviews \\
\hline \multirow[t]{2}{*}{ Phase 1} & $2007-2008$ & 7 Frodistiria & $62 \mathrm{Ss}-7 \mathrm{Ts}$ & Class Observations-Teacher \\
\hline & & & & Interviews \\
\hline \multirow[t]{8}{*}{ Phase 2} & $2008-2009$ & 1 Frodistiria & 130Ss-10Ts-1DOS & Field notes, audio and video \\
\hline & & & & recordings of 'Action' lessons, \\
\hline & & & & questionnaires to all primary \\
\hline & & & & students and their parents, \\
\hline & & & & interviews with DOS and Proficiency \\
\hline & & & & students, DOS observations of \\
\hline & & & & 'Action' lessons, Class observations \\
\hline & & & & by researcher. \\
\hline
\end{tabular}


This multi-method strategy is considered to be the most appropriate for this study, as it allowed the phenomena of early language learning to be analysed from different perspectives. As shown in the table above, the study was conducted over a two-year period. The research included observations of English language lessons in both primary state schools and frodistiria, concentrating on young learners aged 7-11. The number of students in the language lessons observed in state schools was from 20-25 students and 5-12 in the frodistiria. The pupils that participated in the investigation studied in general English language programmes in the morning. Language lessons at the frodistiria took place in the afternoons, serving the purpose of supplementing the morning language lessons. Additionally, semi-structured interviews with 14 English language teachers from all 14 schools (state and frodistiria) were conducted, providing the opportunity to probe more deeply and explore the interviewee's opinions. Specific classes were systematically observed for five weeks each, in the mornings in state schools and in the afternoons in frodistiria. Language lessons and observations took place when English language lessons were carried out, twice a week for one school year. Coded forms were used to record observations for a ten-minute period, which was divided into six minutes of systematic observation, followed by four minutes of contextualising notes and data. Unstructured discussions supplemented the interviews, and opportunities were given for the researcher to seek clarification and ask questions based on the data collected in observations.

When implementing action research, the dilemmas and considerations are vast and complex, since the action researcher was both a researcher and a teacher and was expected to perform a dual role in an environment where no variety of research had previously been conducted. In the current study, there was a specific focus on two groups of children. One class of beginners aged 7-9 and a class of intermediate students aged 9-11. The two levels were chosen in order to investigate the element of change with a group that had experience of language learning in this context and a group that was about to start. The intermediate group had been studying English at the frodistiria for four years and parallel to this, three years at (state) school. A research journal was kept during the course of the study to keep a record of a rich and detailed account of various routine procedures, phases of daily lessons and to record any particularly interesting or theoretically significant events. The young, teenage and adult language learners who attended classes at the frodistiria were requested to complete questionnaires that focused on their lessons both at the frodistiria and primary state schools. A total of 116 questionnaires were given to the students at the end of the school year and were returned immediately. Item analysis was completed at the pilot stage to examine the quality of items included in the questionnaires. 


\section{The English Language Classroom Environment in State Schools}

The nature of the state school classrooms observed was quite similar from school to school, regardless of the area in which the school was located. It was clear that the English teachers were considered visitors to these classrooms and only mainstream teachers could organise the environment of the classroom as they desired. Only two classrooms revealed signs of language learning taking place. Teacher 12a was provided with her own classroom and Teacher 1oa had a few English posters on the walls of the classroom. The other language teachers did not attempt to make changes and revealed in interviews that they did not want a dispute over such matters with their colleagues. Language teachers were expected to keep a distance from the structure of the classroom, which makes it difficult to make alterations in the classroom's environment, even though this may make a difference and have an impact on classroom management.

The year the observations began (2007), the Greek Ministry of Education had altered the mainstream Greek syllabus by introducing the use of new course books designed to encourage mainstream teachers in state schools to apply a cooperative approach to learning in their classrooms. The drawback to this rather radical attempt, since the Greek education system has been known to be highly traditional in its approaches in primary education, is that mainstream teachers had limited guidance on how to put this into practice. Unfortunately, teachers did not have any training or receive any practical information on how to manage and organise group work. Although some did put effort into adopting a new environment in their classrooms, their enthusiasm soon faded when they realised that they were not prepared for the problems associated with a cooperative environment and were not aware of how to prevent such problems from occurring.

This attempt of change for mainstream teachers also had an impact on the English language lessons, where there was no change in their curriculum or syllabus and no input on how to implement, organise and manage the situation. English language teachers that entered the class for 45 minutes were upset to see a seating arrangement that made no sense to them, because as Teacher $13 \mathrm{a}$ stated: 'I don't know why the teacher insists on this setting. It makes it difficult for children to face the teacher's desk'.

However, only three out of seven schools followed such classroom seating arrangements. The rest were of a teacher-centred environment, which was considered the norm in primary state schools in Greece, particularly in this region: a traditional teacher-fronted structure, columns and rows of desks and 
chairs with pupils facing their teacher and her desk. This specific layout was most convenient for teachers who wished to apply a lesson where students were being examined, a term used in Greek classrooms. An example of this occurred during the study when three of the teachers were observed holding a small notebook, asking students theoretical questions on grammatical phenomena and recording the accuracy of their answers, which they would use to evaluate their overall performance at the end of the semester, when parents were given their children's school reports.

The other three classrooms followed a different layout which had no specific purpose or organisation pattern. The structure was mostly chaotic as some classrooms attempted to present an ad hoc cluster of chairs and desks; others tried a semi-circular seating, all the while not encouraging students to interact even though they were seated in the appropriate layout. These structures were not kept in their initial form and desks were arbitrarily set without being placed back, resulting in the learners often not having any sense of spatial organisation and positions appropriate for any type of communicative or cooperative activity. Additionally, seating arrangements had not changed from the beginning of the school year for any activity or purpose, even though desks and chairs were movable.

The classroom environment was a neglected source in the context the research took place, and even though this was evident in the eye of the researcher, when interviewed, the language teachers who participated in the study expressed their anxiety for other issues that were considered more influential, such as a poor syllabus, outdated course books and lack of facilities, to name a few. Within this context, teachers appeared to have abandoned the idea of improving the classroom: firstly, because the buildings were relatively old and secondly, because language teachers in state schools were considered outsiders, where teachers entered the classroom as guests and were requested not to change anything because this would disrupt the course of the rest of the lessons. Five out of seven language teachers stated that their lessons were considered an intermission for mainstream teachers and students. They believe children to be less motivated to participate in any way since most children attended language lessons at frodistiria in the afternoons, in classes with fewer students who were all of the same language level. According to Mattheoudakis and Alexiou (2009), a unique feature of foreign language education in Greece is a thriving private sector where students attend their after mainstream school. The high percentage of children who attend private language institutions indicates the dissatisfaction that exists with regard to the language teaching in state schools. The socio-emotional atmosphere, the low self-esteem of teachers, the 
uninspiring target language use and poor classroom management work against the language-learning process.

\section{The English Language Classroom Environment in a Frodistiria}

Observations revealed a number of differences between state schools and frodistiria. Frodistiria, as language institutions, focused entirely on languages, which was obvious to the observer from the very first visit. The posters on the walls, the listening tasks coming from classrooms and students' drawings of London or Paris were only a few indications of the emphasis on a foreign language environment.

Within the region where the study took place, classrooms in frodistiria provide a wider range of critical contexts for language learning. Many factors combine and interact in order to create an appropriate classroom environment with variables, which include structural components, such as teachers' organisation of classroom materials and supplies, frequent language opportunities, exposure and stronger classroom management strategies. Teachers' organisation of classroom materials and supplies, for instance, were observed to differ markedly from state schools, having a significant impact on the quality of the learning environment. These differences and other factors all contributed to making the classroom environment more pleasant, where clear goals were presented to the students and their parents. It is necessary to mention at this point that frodistiria are private institutions; therefore, they choose to improve their facilities regularly and in most cases, have the financial ability to do so. State schools are not supplied with funding for the improvement of the classroom environment or the latest technology to the same extent. Observations recorded that state schools were provided with minimum facilities. The students who attended frodistiria were aware that they would have responsibilities and a purpose, even if that purpose was passing future language examinations for the attainment of a certificate. These goals were mostly implanted by parents who consider language lessons at frodistiria necessary for their children's future. Language certificates are essential for survival in the competitive and distressed Greek employment market, and the employees of tomorrow will likely need a strong educational background to succeed.

The classrooms were similar from frodistiria to frodistiria, meaning that they were equipped with what were considered basic facilities, such as a whiteboard and a CD player. One out of seven classrooms had a computer, which was used once during observations, for games where students took turns 
approaching the teachers' desk, where the computer was placed and play a round each while others sat behind their desks anxiously awaiting their turn. There were English language posters, phrases and words written on colourful cards around the wall of the classroom, labelling various objects in full view of the students.

The layout of the classrooms in frodistiria was analogous to those in state schools. In the private sector, the school authority predetermined most of the physical environment. There was a preference for teacher-centred environments, as well as a tendency towards examination-focused instruction from the very start of the learners' tuition at frodistiria. Teachers controlled the direction and pace of teaching, monitored and corrected the learner's performance. Nonetheless, the classroom environment was not as neglected as in state schools. However, in this context, there is a great deal of competition among frodistiria; therefore, the owners pay more attention to what some may consider minor details, because of the fact that it may attract more customers.

Understandably, language learning in state schools and frodistiria faces many challenges; however, ensuring a supportive classroom environment can be regarded as a suitable starting point. It may not determine how effective teaching can be, but it can be a contributing factor. Furthermore, with simple changes it may be possible to encourage an entire new attitude towards learning. By focusing on classroom variables that promote foreign language learning, language teachers have the ability to support language opportunities, exposure and classroom management strategies. In the following section, the effects of the teacher-centred context and the outcomes of classroom management and organisation will be discussed.

Classroom Management and Organisation and the Effects of the Teacher-Centred Context

State school language teachers blamed the perception pupils and parents had towards them, making them feel inadequate, since their work was not taken seriously. Pupils' dependence on frodistiria alone resulted in them not focusing on the language lessons provided at state schools. Language teachers at state schools continued to work through the course book and did not make any attempts to introduce something new and more challenging despite being fully aware that the level of their lessons is extremely low for the pupils in question. As Teacher 15a mentioned in an interview, teachers were not required to use the course book or complete it by the end of the school year; nonetheless, they chose to diligently employ it even though children seemed to resent it, and they themselves were not happy with the content. In relation to this, as Teacher $17 \mathrm{a}$ reported, as children grew older, the majority would become increasingly less 
interested in their subject, so that by the time they reached Year 6 they would become even more difficult to manage than when they were younger. Teachers blamed the situation on the frodistiria, claiming that because the lessons that take place there are of a more rapid pace, children are familiar with the material presented in their class. This data relates to Smith and Larsett's (1999, p. 7) argument that:

[...] difficulties in learning and consequent problems with behaviour often happen because the content of a lesson is not matched to the ability of the pupils to whom it is delivered. Because persistent failure can easily result in disgruntled disaffection, careful scrutiny of the curriculum by subject departments and by individual teachers is needed to ensure that it is appropriate.

Data gathered from the observations in state schools indicated that teachers regularly interrupted their lesson in order to make a critical comment on something a pupil may have been doing, which was usually trivial and could have been dealt with privately. Kounin (1970) describes this as stimulus-bounded events in which the teacher draws the attention of the entire class from an on-going task to an insignificant action that does not necessitate attention. One example of this occurred when the researcher had been observing a teacher explaining a grammatical point. She was writing examples on the board when she became aware of one of the students in the back writing on a piece of paper instead of their exercise book, used especially for grammar lessons. When the pupil explained that he had left the activity book at home, she commented that his grades will decrease if he continues this behaviour, a warning that was frequent among teachers. Observation data showed that other students started commenting on this among themselves, and all communication between the teacher and the pupils rapidly vanished, resulting in the teacher needing to take additional time to reinstate the children's concentration. This conversation may not only have a negative effect on a child's willpower to participate, but also took valuable time out of the task. If the teacher draws her pupils' attention towards such events, she makes it difficult for them to stay focused and actually appreciate what it is she is trying to teach them. These signs of ineffective managing often disrupt the course of learning and are some of the elements that lead parents to believe that the work done in state schools is not adequate, compared to the effort teachers make at frodistiria.

Positive reinforcement was rare and occurred mostly when children successfully completed a task and was repeatedly addressed to the same children, usually those seated in the front rows. There were, as the data confirms, 
teachers who ignored pupils' misbehaviour for most of the lesson and worked with the children who were seated in the front rows. If the situation became unbearable, the teacher would yell at the children until there was absolute silence in the room. According to Collin and Laslett (1993), it is often difficult for a teacher to attend to every sign of misbehaviour, though the emphasis must be planned ignoring, rather than hoping that the provocative nuisance will exhaust itself. As most teachers were recorded to explode, when ignoring misbehaviour, it did not seem planned but a management technique they had adopted, which was effective for a short amount of time. Nonetheless, this was considered a suitable attempt to manage misbehaviour.

'We generally do not have behaviour problems in primary school. They are still at an age where they are easily disciplined. If you yell at them once or twice they will eventually calm down' (Teacher 13a).

Learners were seated in rows and faced the teacher, who was the centre of the communication network, as mentioned earlier. Language teachers naturally felt this was the right way a classroom should be organised after years of being exposed to the same environment as students themselves, i.e. their own apprenticeship of observation, as Dörnyei and Murphey (2003) identify it. Another valuable point they make is that teachers do not often realise that they have a spatial advantage to the students. They are able to see everyone and face anyone they wish, assuming the same for the students. However, for language lessons especially, the principal means of learning is the interaction between members of the classroom.

In relation to the above point, there was a particular perception language teachers had concerning group and pair work. In interviews, teachers appeared to be against employing any form of cooperation when tasks were being conducted and would only consider it when students played games. In most cases this was infrequently employed, especially with children in Years 5 and 6 since, according to all teachers, students stopped appreciating these activities when reaching the age of 10 . Interviews revealed that six out of seven state school language teachers were not aware of the concept of cooperative learning in class and referred to group work as an extracurricular project that was too complicated for the young learners of Years 3 and 4 .

Teacher 16a: 'I usually do not assign group work to students of Year Three or Four; they are too young. At the end of every chapter of the book, I assign a project and put them into groups, and they decide whose home 
they will go to in order to complete it. We would use the end of one of our lessons for them to present their pictures or posters.'

Six out of seven teachers considered pair work related only to a reading task, in which students read out dialogues from the book aloud and translated afterwards.

Teacher 15a: 'I use the pair work given in the course book where there are dialogues and the pairs read them aloud, conversations such as 'How old are you?' and so on. I generally do not use pair work a lot because it is not offered in the course book. I do, however, believe that this task helps their language development. As students read to each other, they hear each other and translate, and this helps them develop their speaking in the foreign language'.

When an interactive in-class form of learning was brought to their attention, all teachers stated that theory is different to practice. Children are not familiar with group and pair work, and the use of it would not be fruitful nor benefit or contribute to any learning. It was thought that the pupils who were at a higher level than others would complete tasks and simply provide the information to those who were at a lower level. The problems that arise from the introduction of group work are many and, according to teachers, there is not enough time to discipline pupils and apply new classroom management techniques, therefore, this approach would only add a new dimension of confusion.

Teacher 17a: It is a waste of time. It would take too long to calm the children down and actually get something done. We do not have much time for the actual lesson. There's a lot of noise, and the weak students do not participate, practice is different to theory, the reality is that there are no results. Children do not learn from their peers; they just copy from each other'.

This statement contrasts sharply with the view of Smith and Larsett (1999, p. 22) who argue that:

[...] group work is considered usually in terms of cooperative learning in a less threatening setting than individual performance. Astute tailoring of tasks or questions can ensure that team or group success depends as much on the least able as on the most able member. Competition can be an enjoyable method of enlivening the learning and recall essential facts, 
but it carries the threat of being the source of heightened illumination of individual ignorance. Working with groups offers the chance of providing the element of excitement without the potential limelight hogging or ego bruising of individual competition.

Equivalent observational study and interview material was collected in frodistiria, where there tended to be a feeling of clear existing aims of the teaching-learning process comprising the language examinations and certifications compared to state schools where the aims were in a blur.

The data gathered from observations revealed that there was a more positive response to the presence of warm colours, spacious areas in a moderate and orderly fashion and fewer children in every classroom, a maximum number of 12. The classroom layout and arrangement of classrooms at frodistiria did not differ substantially from the hierarchical, teacher-centred arrangements in state schools. Students in this context again were seated in rows and communication was only planned to be between the teacher and the students; the goal is for children to pay more attention to what is being presented without interruptions, leaving the teacher to occupy the centre of the communication network. Group and pair work were seen as methods used for play, and teachers were not convinced that they would improve the children's learning in any way. As a result, children generally worked alone or in whole-class presentations (Doyle, 1986).

Teacher 13bF: 'I use it [group work] when playing vocabulary and grammar games and likewise pair work where I get a chance to listen to what they are saying and at the end talk about things they've done right or wrong, not for every lesson though.'

Teacher 11bF: 'Students do learn from interaction, but they learn more from me when I correct them.'

Observation data shows that pupils were well-behaved at frodistiria compared to state schools which, since management techniques and teaching approaches are similar, may be simply because language lessons at frodistiria are taken more seriously by parents and evidently have a similar influence on the children. Language teachers in both sectors feared that they would relinquish control of their classes if they changed the layout and introduced a studentcentred approach that would encourage children to interact, not only with their teacher, but their peers as well. The following section presents the findings of 
the action research and the effects age-appropriate classroom management had on a student-centred environment.

\section{The Evaluation of the Classroom Context through Action Research}

As one part of the action research procedure, the 'traditional' layout of the classroom was not rearranged when the beginners were first welcomed. The children were seated in rows, as they would be normally, so that they would not undergo a change from the very beginning. With the annual start of the new school year (following the year where the qualitative research in state schools and frodistiria took place), there was general enthusiasm when students returned to the frodistiria after the summer holidays, which quickly faded as the typical situation in classes progressed. The curriculum assigned was oriented to a course book and children were obliged to go through every bit of homework reading out each task, taking turns and receiving feedback. The children would become extremely quiet, awaiting their turn without receiving any meaningful instruction by the teacher and their engagement was more mechanical than spontaneous and communicative.

After analysing pedagogical structures and activities in state schools, where children were not exposed to an interactive student-centred environment, the researcher/teacher anticipated that an immediate exposure to change at the frodistiria would confuse or maybe even intimidate YLLs. This would make the adaptation of any type of change even more difficult for them to become accustomed to. Since the children were very young and familiar with a predominant discourse under the direction and control of the teacher, the new environment being introduced gradually was regarded as likely to be more efficient. The intermediate group, for instance, was accustomed to routine lessons, at the frodistiria and at their state school, as they were seated in rows next to the same children they were seated next to every year. Therefore, as a first step, I attempted to greet students as they walked into the classroom. Being present before the class arrives can institute a role of host. The teacher, in a discreet manner, can greet the students and highlight a sense of authority without that being intimidating to the children. Consequently, the teacher has the comfort to ensure that the classroom is in an appropriate state and that all that is needed for the lesson is there. This will 'provide the mental composure essential to relaxed assurance' (Smith \& Laslett, 1999, p. 4). This 'technique' was not observed in any of the state schools or frodistiria; however, it was a simple way to ease students in the classroom and help teachers reduce misbehaviour, to some extent. 
As a part of the introduction of the set up, the rules of group work and its purpose were explained to students and parents in writing. It was also emphasised that stars (a form of reward on a poster next to each child's name) were to be used frequently if pupils followed the guidelines. Great emphasis was placed on the way they behaved towards each other and children were warned that there would be no rewards if any kind of bullying, either physical or verbal, occurred. With the introduction of the 'stars', punishment (for instance, lower grades as mentioned earlier) was replaced with rewards since there was a focus on good behaviour rather than bad, where the teacher expects the best from the learners. As Doyle (1986) has argued on the issue of solving such problems, classroom management is a process of attending to the issue of order in classrooms. The problems of misbehaviour and student engagement are not insignificant; however, they are not the language teacher's primary issues. The teacher's primary and foremost management task is to establish and maintain work systems rather than punishing misbehaviour. Nonetheless, the physical characteristics of the classroom in general are often neglected (Weinstein \& Mignano, 1997). The milieu is one aspect of classroom organisation that can reduce the potential of serious disruption by avoiding pupils becoming discouraged, feeling inadequate, incompetent and seeking attention any way possible as a sign of lack of confidence or loss of interest (Smith \& Larsett, 1999). The environment can provide the teacher with opportunities when the necessary attention is commanded. This does not imply that organisation of a pleasant learning environment is a simple task. The primary teacher must have a high organisational ability in order to be successful. Kyriakou (1992) argues that the appearance of the classroom indicates to children the effort and care that the teacher puts into providing them with an environment that will make them feel comfortable and is advantageous to learning. When children enter a language classroom, especially if it is their first encounter with the foreign language, they need to feel that they are entering an environment where they can feel safe and welcome. An environment that they perceive as hostile may bring about negative feelings that may be difficult to discard at such a young age. Colours, drawings, posters can intrigue students and bring out positivity that can guide them all through their course and facilitate the task of applying successful classroom management techniques in the teacher's starting stage. The general displays of the language classroom, as Cullingford (1991) states, can make a distinct impression on the pupil.

Based on the documented evidence during the action research, it was interesting to note from the lesson observation data that, at the start of this newly established seating arrangement, the pupils with strongest personalities 
dominated the groups. There was a need for repetition of the rules and the purpose of group work in order for all members of a group to participate and put forward their ideas and knowledge equally. This took some time, especially for the beginners' group. They were of a younger age, which made them more reluctant to take risks. They needed constant reassurance that they had as much to offer as their peers. By the end of the school year, with systematic reassurance, positive reinforcement and practice, all group members played a significant part in task completions and cooperated well together in response to given time limits by which children were expected to complete their task so as not to overlap the next planned activity. According to Wright (2005), time limits are considered boundaries for formal education but can be porous as well. In these tasks, children assigned roles to each other, cooperated and stayed focused on what was asked of them. The participants of this research responded well to time limits and were determined to meet them. Additionally, the time limits assisted the teacher/researcher in the organisation of the lesson.

As a further element of this research study, all teachers of the frodistiria were encouraged to observe the researcher's lessons once a month and in that time, they were asked to take notes of tasks they felt they could perform in their own classes and methods they would like to adopt to improve their lessons. After a number of observations, teachers were convinced that group and pair work were not just theoretical outlooks. They slowly became convinced that the techniques they witnessed were possible in practice. Two months prior to the end of the school year, they conducted observations of these teachers' classes, during which they adopted a student-centred approach. It was evident that the teachers felt nervous at first. For this reason, the first two lessons were not taken under consideration. The language teachers needed their time to get used to the idea of observations since this was something entirely new to them and, once they felt more comfortable (after Lesson 3), data was recorded. As their lessons progressed, they became more confident. By the end of their lessons, they were more able to ignore being observed and had become entirely involved in the lesson and the outcomes. They later commented that they were pleased to experience full participation from the students, and productive cooperation and positive behaviour, as reflected by the quote below:

Teacher 1400: I was afraid that when I introduced group work most students would see it as an opportunity to copy the work of the stronger ones. I was given the impression though that when I explained what was considered appropriate cooperation and that it would be rewarded, the students immediately made great effort to carry out the task as they were instructed to and actually enjoyed doing it. 
The teacher was not wrong to have second thoughts about the approach of a student-centred environment. The teacher/researcher also came across difficulties when first introducing group and pair work to the children at the frodistiria. Although, there was a belief that this new approach would be more of a challenge for the beginners, it turned out to be more difficult for the intermediate group to adopt. Having been used to a teacher-centred approach at school and the frodistiria, they were not sure how to handle this new freedom given to them by a new teacher. The intermediate class enjoyed the fact that they would be working with their peers; of course, some did see it as an opportunity to lose focus and misbehave, which took some time for them to overcome. The management technique of rewarding good behaviour with stars expedited the process. After the first month, when 'Great Worker' certificates were given in a special ceremony held to celebrate children's achievements, the students started realising the benefits of gaining as many stars as possible. Once they were rewarded with more stars while working together in their groups and focusing on their task, they could see that they learned whilst having fun.

The results of the current study have shown that classroom management and organisation combined with a communicative and interactive environment are factors that contribute substantially to progress in foreign language learning and teaching. Undoubtedly, an increased knowledge of how to apply effective classroom management coupled with an understanding of the potential effects of a student-centred interactive environment would benefit individual teachers and their students. Furthermore, teachers should be trained and prepared beforehand in how to apply effective classroom management and organisation, appropriate methodology and awareness of key elements of classroom life such as space management and pupils' engagement are essential to any educator. The language lessons can become effective within a pleasant non-threatening environment where most students can be involved, active and participative, an element which was not observed in traditional teacher-centred environments. When teachers have undergone the necessary training, they will be able to confidently maintain the students' involvement and choose the appropriate material that would appeal to the learners and their age groups.

\section{References}

Collin, J. S., \& Laslett, R. (1993). Effective Classroom Management, a teacher's guide. Routledge Falmer. Cullingford, C. (1991). The inner world of the school, children's ideas about school. London: Cassell Educational.

Dörnyei, Z., \& Murphey, T. (2003). Group Dynamics in the Language Classroom. Cambridge: 
Cambridge University Press.

Doyle, W. (1986). Classroom Organisation and Management. In M. C. Wittrock, Handbook of Research on Teaching. New York: Macmillan.

Kaulfer, W. C. (2006). The Management of a Foreign Language Class. The Modern Language Journal, $15,1$.

Kounin, J. (1970). Discipline and Group Management in Classrooms. New York: Holt, Rinehart and Winston.

Kyriakou, C. (1992). Essential Teaching Skills. Hemel Hempstead: Simon and Schuster.

Mattheoudakis, M., \& Alexiou, T. (2009). Early foreign language instruction in Greece:

Socioeconomic factors and their effect on young learners' language development. In M. Nikolov

(Ed.), The age factor and early language learning (Studies on Language Acquisition) (pp. 227-252).

Mouton de Gruyter.

Paulsel, M. L. (2004). Using Behaviour Alteration Techniques to Manage Student Behaviour.

Communication Teacher, 18(2), 98-114.

Rixon, S. (1999). Greece-Teaching English to Young Learners. The British Council.

Smith, C. J., \& Laslett, R. (1999). Effective Classroom Management: A Teacher's Guide. Routledge.

Weinstein, C. M., \& Mignano, A. J. (1993). Elementary Classroom Management: Lessons from Research and Practice. McGraw Hill.

Wright, T. (2005). Classroom Management in Language Education. Basingstoke: Macmillan Palgrave.

\section{Biographical note}

Christina N. Giannikas, (Ph.D) is a Research Fellow at the Cyprus University of Technology and online events support for IATEFL YLTSIG. She has taught General and Academic English to adults and young learners in the UK and Greece and was a seminar tutor/guest lecturer at London Metropolitan University. Dr. Giannikas was also an assistant researcher for the ELLiE project (Early Language Learning in Europe). Her research interests include communicative language teaching, the use of the mother tongue in language teaching, the study of diglossia, educational policies, early language learning and the use of new technologies in language teaching. 